\title{
Florid papillomatosis of the nipple
}

\author{
Baithma Jothi Dinesh, ${ }^{1,2}$ Firdaus Hayati, ${ }^{3}{ }^{3}$ Nornazirah Azizan, ${ }^{4}$ \\ Nor Faezan Abdul Rashid ${ }^{5}$
}

${ }^{1}$ Department of Surgery, University of Malaya, Kuala Lumpur, Wilayah Persekutuan, Malaysia

${ }^{2}$ Department of Surgery, Queen Elizabeth Hospital, Ministry of Health Malaysia, Kota Kinabalu, Sabah, Malaysia

${ }^{3}$ Department of Surgery, Faculty of Medicine and Health Sciences, Universiti Malaysia Sabah, Kota Kinabalu, Sabah, Malaysia

${ }^{4}$ Department of Pathobiology and Medical Diagnostic, Faculty of Medicine and Health Sciences, Universiti Malaysia Sabah, Kota Kinabalu, Sabah, Malaysia

${ }^{5}$ Department of Surgery, Faculty of Medicine, Universiti Teknologi MARA, Sungai Buloh, Selangor, Malaysia

Correspondence to Dr Firdaus Hayati,

firdaushayati@gmail.com

Accepted 5 September 2019

Check for updates

(c) BMJ Publishing Group Limited 2019. No commercial re-use. See rights and permissions. Published by BMJ.

To cite: Dinesh BJ, Hayati F, Azizan N, et al. BMJ Case Rep 2019;12:e231516. doi:10.1136/bcr-2019231516

\section{SUMMARY}

Florid papillomatosis (FP) of the nipple, or nipple adenoma, is a rare breast tumour, affecting middle-aged group population. A 46-year-old woman presented to us with a cauliflower-like FP of the right nipple with no blood stained discharge or breast lump. FP can be mistaken clinically for Paget's disease and occasionally misinterpreted as invasive ductal or intraductal carcinoma. Extensive intervention, correct diagnosis and prompt treatment are essential. Any breast pathology requires triple assessment including FP of the nipple. Once the diagnosis of ductal carcinoma is excluded, simple complete excision can be undertaken. This is to ensure complete obliteration of disease recurrence and preservation of cosmetic result. We discuss the pathology and psychosocial aspects of FP.

\section{BACKGROUND}

Florid papillomatosis (FP) of the nipple, or nipple adenoma, originates from the lactiferous ducts of the nipple. It is an uncommon benign breast tumour often mistaken clinically for Paget's disease if presented with nipple destruction and occasionally misinterpreted as ductal carcinoma. It was first introduced by Jones back in $1955 .^{1}$ It mostly affects middle-aged group population at 40 and 50 years of age. ${ }^{2}$ FP commonly presents with blood-stained nipple discharge, nipple erosion and induration or growth formation. ${ }^{2}$ As far as we are concerned, this is the first case of an FP masquerading as cauliflower of the nipple. Being a benign lesion, FP can be surgically treated by simple curative tumour resection while preserving the nipple areolar complex cosmetically. We report herein a distinctive case of adenoma of the nipple mimicking a cauliflower and discuss pathology and psychosocial aspects of this issue.

\section{CASE PRESENTATION}

A 46-year-old woman presented with abnormal pedunculated mass with papillomatous surface on top of the nipple of the right breast (figures 1 and 2 ). It was painless and measured $3 \times 3 \mathrm{~cm}$ in size with no contact bleed. There was no other breast lump or any evidence of palpable axillary lymph node. She had no nipple discharge. The patient had noticed the mass 2-3 years prior to her visit, and during that interval the mass had increased in size. She denied of family history of breast or ovarian cancer.

\section{INVESTIGATIONS}

Ultrasonography revealed a heterogeneous lesion arising from the right nipple with minimal

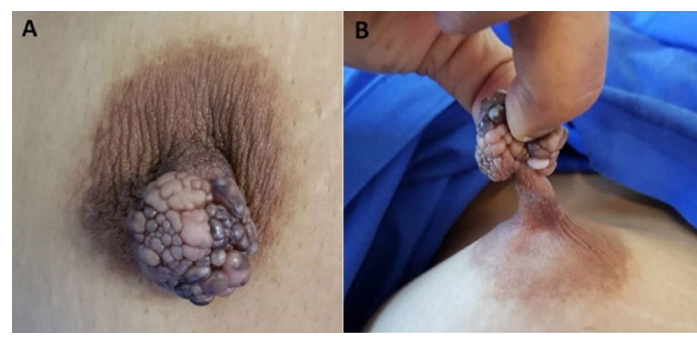

Figure 1 (A) Multiple papillomatous lesions on the nipple surface. (B) Pedunculated mass arising from nipple surface measuring $3 \times 3 \mathrm{~cm}$.

vascularity within. There were neither dilated ducts nor breast lesions. Mammography showed a lobulated mass arising from the right nipple with no microcalcification.

\section{DIFFERENTIAL DIAGNOSIS}

Even it harbours adenomatous component, it is difficult to distinguish from ductal carcinoma in a markedly proliferative and pedunculated growth of intraductal carcinoma. The patient will present with blood-stained nipple discharge and breast mass. Sonographic and mammographic evidence of malignancy will be manifested. On histology, the presence of two distinct layers of myoepithelial cells in neoplastic ducts is diagnostic for adenoma, differs from ductal carcinoma which will be assisted by immunohistochemistry of CD10, p63 or $\alpha$-smooth muscle actin. ${ }^{2}$

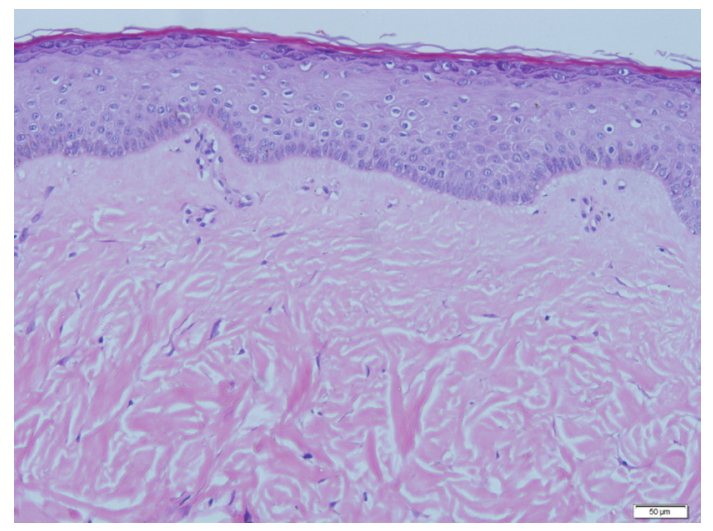

Figure 2 Section shows a polypoidal tissue lined by keratinising stratified squamous epithelium with central fibrocollagenous core tissue. The epithelial lining shows evidence of koilocytic change (H\&E, original magnification $\times 20$ ) . 


\section{TREATMENT}

The patient received local curative excision of the lesion under local anaesthesia. The recovery was uneventful. The histopathological examination was consistent with papillomatosis with no evidence of invasive ductal or squamous cell carcinoma.

\section{OUTCOME AND FOLLOW-UP}

On follow-up at 3 months, the patient had recovered well, and there was no local recurrence with a good cosmetic outcome.

\section{DISCUSSION}

FP is a rare benign breast lesion, identified with various names. It includes nipple duct adenoma, papillary adenoma, erosive adenomatosis, papillomatosis of the nipple and subareolar duct papillomatosis. ${ }^{3}$ The WHO has classified FP as a compact proliferation of small tubules lined by epithelial and myoepithelial cells, with or without proliferation of the epithelial component, around the collecting ducts of the nipple. ${ }^{4}$ It can develop anywhere on the skin surface of the breast. In fact in our case, it appeared immensely on the nipple skin surface itself.

Looking from the cosmetic aspect, the presence of abnormal mass on the nipple surface will influence one's self-esteem psychologically. This can lead to depression, poor libido and avoidance of sexual contact. In addition, the presence of abnormal mass on the nipple will affect the mouthing process of breastfeeding. By having a slightly pointed nipple on the nipple areolar complex, this mechanism will assist in breastfeeding process effectively. On contact between baby's palate and nipple, sucking reflex is triggered, hence lack of this normal anatomy can break the cycle of breastfeeding.

Human papillomavirus (HPV) has been linked to the development of benign proliferative disease. Even majority are asymptomatic, in persistent and prolonged viral infestation, it has been implicated in the development of various malignancies namely cervical, anal squamous cell and even breast carcinoma. ${ }^{56} \mathrm{High}$ risk HPV, especially types 16 and 18, has been found in vaginal, penile, anal and oral flora, which indicates transmission on sexual route. ${ }^{5}$ In our case, similar transmission can be postulated, leading to development of FP, and we believe eventually, it can degrade into breast malignancy. Since the coexistence with carcinoma especially among previous breast FP is proven, thorough breast self-examination and clinical follow-up are warranted when FP of the nipple is confirmed. ${ }^{7}$

It is paramount to diagnose FP of the nipple; hence, an unnecessary surgical resection can be avoided. Since FP is a completely

\section{Patient's perspective}

It is a life-changing experience after having this pedunculated mass resected out. I am so happy with the treatment provided by the surgical team.

\section{Learning points}

- Florid papillomatosis (FP) can be misinterpreted as invasive ductal or intraductal carcinoma.

- Besides having the risk of malignancy, pedunculated FP can lead to cosmetic disfigurement, sexual dysfunction, psychological disturbance and failure to establish breastfeeding.

- In pedunculated FP, simple excision on the nipple carries a good cosmetic outcome.

benign tumour, a limited surgical excision is the preferred option for treatment modality. Surprisingly, in our case, she did not require nipple excision with concomitant reconstruction.

Acknowledgements The authors would like to thank the Director General of Health Malaysia for his permission to publish this article as case report.

Contributors BJD: preparation of the manuscript. FH and NA: manuscript review. NFAR: final revision of the manuscript.

Competing interests None declared.

Patient consent for publication Obtained.

Provenance and peer review Not commissioned; externally peer reviewed.

\section{REFERENCES}

1 Jones DB. Florid papillomatosis of the nipple ducts. Cancer 1955;8:315-9.

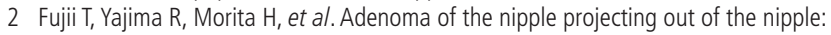
curative resection without excision of the nipple. World J Surg Oncol 2014;12:91.

3 Salemis NS. Florid papillomatosis of the nipple: a rare presentation and review of the literature. Breast Dis 2015;35:153-6.

4 In: Tavassoli FA, P: D, eds. World Health Organization Classification of Tumours. Pathology and Genetics of Tumours of the Breast and Female Genital Organs. IARC Press: Lyon, 2003

5 Salman NA, Davies G, Majidy F, et al. Association of High Risk Human Papillomavirus and Breast cancer: A UK based Study. Sci Rep 2017:7:43591.

6 Ono M, Yoshikawa K, Yamaguchi T, et al. A Case of Breast Cancer Coexisting with Florid Papillomatosis of the Nipple. Breast Cancer 1998;5:87-91.

7 Rosen PP, Caicco JA. Florid papillomatosis of the nipple. A study of 51 patients, including nine with mammary carcinoma. Am J Surg Pathol 1986:10:87-101

Copyright 2019 BMJ Publishing Group. All rights reserved. For permission to reuse any of this content visit

https://www.bmj.com/company/products-services/rights-and-licensing/permissions/

BMJ Case Report Fellows may re-use this article for personal use and teaching without any further permission.

Become a Fellow of BMJ Case Reports today and you can:

- Submit as many cases as you like

- Enjoy fast sympathetic peer review and rapid publication of accepted articles

- Access all the published articles

Re-use any of the published material for personal use and teaching without further permission

Customer Service

If you have any further queries about your subscription, please contact our customer services team on +44 (0) 2071111105 or via email at support@bmj.com.

Visit casereports.bmj.com for more articles like this and to become a Fellow 